\title{
AND THEY LIVED HAPPILY EVER AFTER... OR DID THEY? THE PORTRAYAL OF OLD AGE AND OLDER PEOPLE IN FOREIGN LANGUAGE TEACHING TEXTBOOKS
}

\begin{abstract}
The aim of this article is to present the results of an analysis of the presence of topics concerning old age both as a social phenomenon and as a stage in human life in mainly German, foreign language teaching textbooks. The evidence shows that this subject only appears as a separate thematic unit in textbooks for teaching German as a foreign language. The question, therefore, arises as to why it is only covered in this group of textbooks, but is missing in textbooks used to teach English, Russian or Polish as foreign languages. The subject of old age is becoming more and more widespread in Polish public debate where seniors are slowly becoming not only the object, but also the subject of this discussion. However, this tendency is not reflected in textbooks used to teach Polish as a foreign language. Perhaps Polish textbooks have not yet managed to react to demographic changes in society? Or maybe old age, and the problems of elderly people are not important enough to devote a separate place to them in a medium, which is designed for and mostly used by young people. A textbook is understood in this context as a social medium that co-shapes the image of non-linguistic reality, just like other mass media. On the basis of the analysis of textbooks and the ways various social phenomena are presented in them, it is possible to reconstruct not only scientific discourse in the mother country of a given textbook, but also its social discourse, the thinking of language communities and the changes taking place in individual communities. On the one hand, textbooks present reality as it is, and on the other, they construct its results.
\end{abstract}

Keywords: old age, the image of old age, seniors, textbook, textbook for teaching/learning a foreign language, discourse.

\section{INTRODUCTION}

The original aim of this article was to present the results of an analysis of textbooks used for teaching different foreign languages, which have appeared over the past several decades, in relation to content on old age and older people. However, it was necessary to modify the original intention as it was a problem to collect the right body of texts. This was partly due to the difficulty in accessing older textbooks, but mainly due to the lack of coverage of this topic in publications. The following considerations will therefore present a "here and now" situation, with a few references to the past. It is mainly based on textbooks used for teaching

\footnotetext{
${ }^{1}$ Marta Smykała, PhD, Faculty of Philology, Department of Applied Linguistics, University of Rzeszów, Al. mjr. W. Kopisto 2 B, 35-315 Rzeszów, e-mail: smykala@intertele.pl.

Dr Marta Smykała, Wydział Filologiczny, Katedra Lingwistyki Stosowanej, Uniwersytet Rzeszowski, Al. mjr. W. Kopisto 2 B, 35-315 Rzeszów, e-mail: smykala@intertele.pl.
} 
German, because most material regarding old age as a social phenomenon and a human life stage has been found in them. Textbooks for teaching English or Russian hardly provide any comparative material. In addition this topic is actually absent in textbooks used for teaching Polish as a foreign language. The conclusions reached after these considerations, do, however, concern not only foreign language teaching textbooks, but also didactics in general. If we treat a textbook for teaching a foreign language not only as a medium that transmits strictly linguistic knowledge, but also as a medium co-shaping the image of reality $^{2}$ and as a cultural message intended for a foreign language audience, which does not know a given society and a given culture, then, perhaps, by examining for example textbooks for teaching Polish as a foreign language, we will learn a little about ourselves. We may also learn about the changes that take place in the public arena, in this case in the collective approach to old age. The question that arises as a result of the analysis is as follows: Why has this topic been present in German as a foreign language textbooks for many years, while in others it simply does not exist or is treated only marginally?

\section{GERONTOPHOBIA OR GERONTOCRACY}

In the literature on the subject, there is often talk of the marginalisation of old age, displacing it from the general consciousness, as well as the taboo of death. As Monika Guzewicz and Stanisława Steuden write in the preface to the monograph Oblicza starości [Faces of old age], which they have edited" ${ }^{3}$ : the word "old age brings negative associations nowadays. Western culture promotes the omnipresent cult of youth, its impeccability and selfsufficiency. [...] Contemporary man defends himself against old age, fights its signs, more and more often prolongs the durability of the assets of the young body and behaviour. [...] In Poland, old age is somehow invisible, hidden from life as it plays out"4.

This is confirmed by another researcher, writing about marginalising old age, quoting dr Jarosław Derejczyk, director of the Geriatric Hospital in Katowice: "In Poland, we pretend that there is no old age"s.

But does old age evoke only negative associations? Other patterns come to us from the West. Observations of everyday life show that the status of old age as a phenomenon has been changing, not only in Poland. It is said that there is marginalisation and the "transparency" of old age ${ }^{6}$, crowds it out of public consciousness, but what does this mean? Researchers often emphasise that thinking about old age is very stereotypical and that these stereotypes are mainly disseminated by the media. On the other hand, it is said that until recently, older people have been completely overlooked in the media ${ }^{7}$. So what exactly is

\footnotetext{
${ }^{2}$ Cf. e.g. E. Zalewska, Obraz świata podręcznikach szkolnych do klas poczatkowych, Gdańsk 2013, T. Höhne, Schulbuchwissen. Umrisse einer Wissens- und Medientheorie des Schulbuchs, Frankfurt/M 2006; J. Labocha, Dyskurs jako proces przekazywania wiedzy [in:] Dyskurs edukacyjny, T. Rittel, J. Ożdżyński (eds.), Kraków 1997 et al.

${ }^{3}$ M. Guzewicz, S. Steuden, Oblicza starości we wspótczesnym świecie, vol. 2, Lublin 2015.

4 ibid., p. 9.

${ }^{5}$ M. Potent-Ambroziewicz, Starość w języku młodzieży wspótczesnej, Lublin 2013, p. 7.

${ }^{6}$ Cf. e.g. M. Kita, Językowe rytuaty grzecznościowe, Katowice 2005.

7 In relation to advertising messages, e.g. Lewandowska-Pająk writes about this in Potrzeby osób starszych prezentowane w reklamach telewizyjnych [in:] Oblicza starości we wspótczesnym świecie. Perspektywa spoteczno-kulturowa, M. Guzewicz, S. Steuden, P. Brudek (eds.), Lublin 2015, p. 469-479.
} 
the situation? Is old age subject to public debate? Is it covered in the media? Do we ourselves think about old age?

Only a few years ago this topic hardly existed in the public sphere. Today, one can risk making the statement that the cult of youth is slowly disappearing. Is there, therefore, room for reflection on old age? Old age is increasingly bolder and louder, spoken about in the public sphere (see below). Old age is also present in everyday life. Even if we are young, and we deny the fact of getting older, the presence in the family of our grandparents makes us aware of it. Just as does the presence of other older people in our surroundings. The ageing process of societies as a universal phenomenon imposes "widespread" activities and it can no longer be ignored.

It can be concluded from the literature on the subject that the marginalisation of old age has taken and still takes place, both in the private and public sphere, i.e. in the media, legislation, etc. However, the situation in both spheres has changed quite dramatically in recent years, because:

- older people are often a "power-holding group" (gerontocracy), holding important posts and offices, possessing significant wealth.

- older people are an increasingly attractive target group not only for the pharmaceutical or cosmetics industries and insurance companies (commercial advertising). Admittedly, advertising often replicates the stereotypical image of old age and is often criticised by researchers ${ }^{8}$. Nevertheless it does not change the fact that older people are an increasingly large group of advertising market targets.

- older people constitute a substantial social force, the voice of which is publicly heard, thanks to the media, such as, for example, TV Trwam, Radio Maryja and Nasz Dziennik.

- there are deliberate actions taken to counteract the marginalisation of older people, and their social exclusion, as part of the implementation of EU guidelines (and, among others, for EU money) ${ }^{9}$, through social advertising, TV series "with a mission", from which emerges a quite positive image of old age, the activities of NGOs, such as the Great Orchestra of Christmas Charity, which has been performing for several years including in geriatric wards.

Marginalisation in the private sphere is also less as the self-awareness of the elderly and social awareness of the phenomenon are changing. The results of research show, we approach our old age more consciously ${ }^{10}$, we plan it, we are active in old age (senior clubs, third age universities). The opinions and assessment of older people themselves are changing. In turn, the consequence of raising nuclear families is the failure to take care of ageing parents. It forces us to make public the problems connected with old age. What used to take place in the proverbial "four walls" is transferred to public institutions. Even if most of us do not give ourselves the moral right to refuse to take care of our parents, (often because of external

\footnotetext{
${ }^{8}$ Cf. e.g. ibid.

9 On 22 October 2008, the Parliament and the European Council declared in 1 art. that “ (...) in order to support the Community action in the fight against social exclusion, 2010 is declared the European Year for Combating Poverty and Social Exclusion". Retrieved from: http://www.krakow.pte.pl/ pliki/Polityka\%20spo\%C5\%82eczna\%20kraj\%C3\%B3w\%20UE_Rozdzial_5.pdf (access: 30 March 2017).

${ }^{10}$ Cf. Wciórka, 2007, http://www.cbos.pl/SPISKOM.POL/2007/K_033_07.PDF (access: 30 March 2017).
} 
conditions), children are not always able to provide their parents with proper care. Its institutional form is becoming an increasingly common alternative. It may have been the case that in Poland - thanks to its so-called traditional values - nursing homes are unnecessary. However, recently, more and more of them have been created ${ }^{11}$.

Honorata Jakubowska, Alicja Raciniewska, Łukasz Rogowski state: "However, the increasing share of older people in society and the growing socio-economic importance of this group has not caused a significant change in their stereotypically perceived cultural status"12. Thus, there is no shortage of observations in the subject literature about changes taking place in the public arena. Although these changes are noted, at the same time, it is emphasised that demographic changes do not cause qualitative changes in evaluating old age. While not developing this thread further, I would like to comment on this phenomenon by referring to Mieczysław Gałuszka: "In mass culture and the ideology of consumerism, the phenomenon of a strong exposure to the cult of youth appeared, which automatically depreciated the social position of older people. The basic task of social policy, mass media and many other entities is to valorise the reality of older people and change the perception of old age" 13 .

It seems to be happening. Older people are ceasing to be just an object of the market's interest and become an active subject ${ }^{14}$. As Gałuszka rightly noted, an important role in this field lies in the media.

\section{FOREIGN LANGUAGE TEACHING TEXTBOOKS - THE LANGUAGE AND CULTURE OF A LANGUAGE AREA "IN A NUTSHELL"}

Textbooks, especially school textbooks, are the subject of research mainly in didactics and pedagogy, but also in many other disciplines, including, among others, history of a way of thinking, and, occasionally textual linguistics or a linguistic analysis of discourse.

The purpose of each textbook is to convey specific knowledge. In the case of a foreign language teaching textbook in addition to the transmission of linguistic knowledge (as well as knowledge of the language), it is also used to transmit cultural knowledge, mainly through the representation of a given country or language area using appropriately selected texts (including illustrative material). Textbooks can therefore be treated as media depicting and constructing non-linguistic reality ${ }^{15}$, simplified or generalised (often idealised) messages (statements) regarding language communities (often national) and their value systems, which are also the products of these systems. A modern foreign language teaching textbook

${ }^{11}$ Relevant data can be found on the websites of the Ministry of Labour and Social Policy and in statistical studies, e.g. http://irss.pl/wp-content/uploads/2013/12/domy_pomocy_spo\%C5\%82ecznej_w_polsce.pdf (access: 9 March 2017).

${ }^{12}$ H. Jakubowska, A. Raciniewska, Ł. Rogowski, Patrzac na starość, Poznań 2009, p. 9.

${ }^{13}$ M. Gałuszka, "Siwiejąca populacja: ekonomiczna, spoteczna i etyczna waloryzacja starości", http://www.annalesonline.uni.lodz.pl/archiwum/2007/2007_02_galuszka_83_93.pdf (access: 30 March 2017).

${ }^{14}$ Cf. E. Dałek, Belferska refleksja na temat licealistów recepcji starości... Rozważania w kontekście lektur nowej podstawy programowej z jezzkka polskiego w szkole ponadgimnazjalnej [in:] Oblicza starości..., vol. 1, p. 413-428.

15 Cf. footnote 2 . 
is therefore a specific macro-genre text ${ }^{16}$, in which, in a multimodal form, selected discourses become visible, and in their framework an image of the world of a given language community is constructed - how the given linguistic community sees the individual components of the world, its organisation, the hierarchies prevailing in it and the accepted values ${ }^{17}$. If the foreign language teaching textbook is written by representatives of that culture and that world, it can be viewed as a particular showcase for their way of perceiving that world and of themselves in that world. It also conveys the message: "we want to be perceived in such a way". A textbook is therefore a cultural and linguistic offering of a certain mindset. Because, as can be seen in the language itself how "people in different epochs and social groups think, feel and want differently, and vice versa, so language in the sense of the spoken word, (not a linguistic system but a language in use) shapes their thinking, feeling and will" 18 . According to Hermanns, the sum of the habitual thinking and beliefs characteristic of a social group, and their disposition to such and no other way of thinking, these are the "trivial thoughts of a given group"19. Thus what is habitual, general, and serial (repetitive), are the thoughts that a group considers to be true. From a psychological point of view, we can talk about certain attitudes or attitudes characteristic of a given social group. These characteristic collective ways of thinking, feeling and formulating judgement are reflected in linguistic behaviours and are a reflection of collective knowledge and attitudes. Contemporary linguistic discourse analysis is interested in the relationship between collective knowledge and language. For, as Waldemar Czachur and Dorota Miller put it: "knowledge is inseparable from language, so discourse analysis must have as its basis specific language realisations as forms of the existence of that knowledge, and as for language analysis, it must be applied to specific material consisting of words and texts ( $c f$. Foucault 1977: 140). [...] The categories of thought and ways of perceiving reality which dominate at any given time and place can only be reconstructed on the basis of an analysis of language behaviours" 20 .

Linguistic analysis of discourse is a dynamically developing discipline of linguistics, the subject of which is the discourse usually understood as a set of texts or related themes, or a trans-textual structure, in which intertextual connections occupy an important place ${ }^{21}$.

${ }^{16}$ In Polish literature on the subject, there are few comprehensive studies of this genre from the point of view of linguistics, pragmatics and knowledge about culture. In this respect, the publication by J. Nocoń is a unique item, Podręcznik szkolny w dyskursie dydaktycznym-tradycja i zmiana, Opole 2009.

${ }_{17}$ Cf. R. Tokarski, Stownictwo jako interpretacja świata [in:] Wspótczesny język polski, ed. J. Bartmiński, Lublin 2001, p. 366.

${ }^{18}$ F. Hermanns, Sprachgeschichte als Mentalitätsgeschichte. Überlegungen zu Sinn und Form und Gegenstand historischer Semantik [in:] Sprachgeschichte des Neuhochdeutschen. GegenständeMethoden - Theorien, ed. A. Gardt et all., Tübingen 1995, p. 75

19 ibid.

${ }^{20}$ W. Czachur, D. Miller, Niemiecka lingwistyka dyskursu. Próba bilansu i perspektywy, "Oblicza komunikacji” 2012, 5, p. 28.

${ }^{21}$ More on discourse, see for example in: Z. Bilut-Homplewicz, Prinzip Perspektivierung, Germanistische und polonistische Textlinguistik - Entwicklungen, Probleme, Desiderata. Teil I: Germanistische Textlinguistik, Frankfurt am Main 2013; W. Czachur, Diskursive Weltbilder im Kontrast, Wrocław 2011; B. Witosz, Kategoria dyskursu w polonistycznej edukacji akademickiej [in:] Jak analizować dyskurs. Perspektywy dydaktyczne, eds. W. Czachur, A. Kulczyńska, 
Within the framework of Germanist linguistic discourse analysis, however, little attention has been given to textbooks as such ${ }^{22}$.

Every foreign language teaching textbook, but not only these texts, can be considered as such a comprehensive message, as linguistic behaviour in which a certain collective knowledge is manifested, or as an expression of the mindset of a particular community, and the result of a discursive image of the community, or "discursively profiled interpretation of reality, that can be expressed in the form of a collection of views about the world, about people, things and events" ${ }^{\prime 2}$. Referring to Bartmiński, a textbook can be seen as a result of a linguistic image of the world. As the researcher rightly observes, this image: "Is an interpretation, not a reflection, it is a subjective portrait, not a photograph of real objects. This interpretation is the result of subjective perception and conceptualisation of reality by speakers of a given language, so it is clearly subjective, anthropocentric, but at the same time, intersubjective in the sense that it is subject to socialisation and becomes something that connects people in a given social circle, makes them a community of thoughts, feelings and values; something that is secondary (to what extent - is already the subject of dispute) to the perception and understanding of the social situation by members of the community"24.

If we treat textbooks as places where "materialisation" of the linguistic or discursive image/images of the world occurs, or as a result of the mindset of a given community, we must remember that textbooks and "textbook worlds" are created by subjects that "can express, as much as they allow or enable them, a relatively open description of the cultural system of a given community. Culture is a space of possibilities and limitations for the creation and implementation of discourses" 25 .

If there is some of this content in the textbook, this usually means that it exists in the culture and in the sphere of public discourse, and is conceptualised and hence assessed.

\subsection{Factors determining the choice of textbook content}

In general, the choice of specific textbook (foreign language) content is influenced by two opposing tendencies:

- the tendency to unify, resulting from anthropological premises: regardless of the geographical latitude in which we live, we, as people have specific needs and ways of

Ł. Kumięga, Kraków 2016, p. 19-39; A. Duszak, Tekst, dyskurs, komunikacja międzykulturowa, Warszawa 1998 at al.

${ }^{22}$ Textbooks as a subject of study of textual linguistics and contrastive textology cf. e.g. K. Adamzik, Kontrastive Textologie am Beispiel des Schulbuchs, "text and discourse - text und diskurs" 2012, 5, p. 53-91; P. Dreesen, J. Judkowiak, Bierni na Wschodzie, ponoszacy zbiorowa winę i oczywiście obecni w Europie - krytyka niemieckich i polskich podręczników do historii w oparciu o kontrastywna lingwistykę dyskursu, "text and discourse - text und diskurs" 2012, 5, p. 93-126; C. Gansel, Zum textlinguistischen Status des Schulbuchs [in:] Linguistik und Schulbuchforschung. Gegenstände - Methoden - Perspektiven, ed. J. Kiesendahl, C. Ott, Göttingen 2015, p. 111-135; J. Kiesendahl, C. Ott [ed.], Linguistik und Schulbuchforschung. Gegenstände - Methoden - Perspektiven, Göttingen 2015.

${ }^{23}$ W. Czachur, Dyskursywny obraz świata. Kilka refleksji, "text and discourse - text und diskurs" 2011, 4, p. 87.

24 J. Bartmiński, (2010), quoted after W. Czachur, Dyskursywny..., p. 82.

${ }^{25}$ W. Czachur, Dyskursywny..., p. 87. See also W. Wiater, Das Schulbuch als Gegenstand pädagogischer Forschung [in:] Schulbuchforschung in Europa - Bestandsaufnahme und Zukunftsperspektive, ed. W. Wiater, Bad Heilbrunn 2003, p. 8. 
dealing with everyday life which are common to all of us, that is why in textbooks regardless of the language being taught - there is information on specific thematic areas e.g. family, daily life, work, leisure etc.) and various guidelines (e.g. EU ones, such as the European certification system $\mathrm{CEFR}^{26}$ or, for example, departmental, regarding textbooks authorised for school use).

- a tendency to diversify resulting from the cultural specificity of a given language area and its value systems ( $c f$. considerations about the discursive and linguistic image of the world). Of course, the choice of content is also influenced by the authors, but their freedom also has its limits. In particular, the content of a textbook depends on:

- standard requirements (here: CEFR and ministerial standards),

- market requirements (books must be sold),

- individual preferences of the author/s (the antidote to excessive subjectivity are discursive restrictions and market requirements),

- expectations and abilities of the target group. In the case analysed here, the recipients are mostly young people. The content correlates with their age and level of language proficiency.

- the purpose of the didactic process. In the case of a foreign language teaching textbook, the aim is to learn/teach a language and build a picture of the world of a community using this language by showing the cultural specificity of a given country, creating its "business card". It is impossible to avoid duplicating certain stereotypical ideas completely. On the other hand, foreign language teaching textbooks contain information about the characteristic, specific and important elements of a given country. The choice of topics and content - especially at more advanced levels (more or less from B1 +) are examples of what is being talked about in a given country. When examining language teaching textbooks in diachronic terms, one can recreate a specific intersubjective history of socio-economic and cultural changes in a particular country or language area. The language used needs to remember to maintain an appropriate level of abstraction and to take into account any time shift.

- restrictions, also reflecting the limits set by the discourse. By restrictions, I here mean assumptions, not to violate certain cultural taboos, both with reference to the culture presented in the textbook and culture in general, especially if you do not know who the recipient of the content contained in the textbook will be. In any event, even if the recipient is known, topics deemed as sensitive and overly controversial in some cultures for example equality of women, their rights, role in the family and society, gender and genderism, same-sex relationships, etc. are often avoided.

\section{IMAGE OF OLD AGE PORTRAYED IN FOREIGN LANGUAGE TEACHING TEXTBOOKS USING THE EXAMPLE OF TEXTBOOKS USED TO TEACH GERMAN AS A FOREIGN LANGUAGE}

The research material consists of textbooks, available in the Goethe Institute Mediatheque at the University of Rzeszów (UR) Library (over 100 different textbook items and supplementary material, exercise books and teachers' books), at the POLONUS reference library of the Centre for Polish Culture and Language for Poles from abroad, operating at

${ }^{26}$ CEFR - Common European Framework of Reference for Languages. 
UR (about 50 textbooks), the author's own resources and the resources of lecturers at the Foreign Language Centre, and the English Studies and Russian Studies departments at UR.

In further considerations, I have omitted those cases in which "grandparents" appear in connection with the topic of "family". In more recent German textbooks, in any case, grandparents are often omitted when the topic of the family is discussed. This is a relatively new tendency, but it is not so much about the marginalisation of old age - because old age appears relatively often in the newer textbooks - but it appears as a separate subject, which corresponds to social reality. These days multi-generational families are encountered less frequently, and the bonds between grandparents and grandchildren are relaxed. However, if grandparents are included "incidentally", alongside the topic of the "family", it is usually in a very stereotypical way and there is in fact no difference between textbooks used to teach Polish as a foreign language and textbooks teaching German as a foreign language. I will simply mention that authors use positive stereotypes, "according to which older people are polite, cheerful, trustworthy, influential" 27 .

\subsection{Textbooks used to teach Polish as a foreign language}

In textbooks teaching Polish as a foreign language, the topic of old age is essentially absent (apart from in content devoted to the family - showing a grandmother and grandfather as family members). Among the material analysed, old age is a supporting (secondary) subject, in only a few publications:

1) as part of the exam sample paper at $\mathrm{C} 2$ level, related to the main theme volunteering: a photo of an older person climbing the stairs with difficulty in Celuje in $C 2$.

2) two texts (Someday you will come back here), serving as a starting point (stimulus) to express indignation. The first text shows how difficult it is to cope with parents with dementia. This is portrayed as a situation that one cannot be prepared for and which always "overwhelms" children. The second text discusses, as a counterweight, the positive influence of relationships with grandparents on a child's mental development. The latter text emphasises the benefits of having grandparents, while the former painted in very sombre colours depicts the infirmity of old age, which also is a burden on the carers of people with dementia. ("Carers of older people often get depressed" - ibid.), it is also mentioned that the problem is hidden away in Poland, there is nowhere to consult a psychologist. In addition, this chapter contains other texts intended for independent reading and numerous grammar exercises, not related to the topic of old age. The topic appears once again at the very end of the chapter in the form of the task "Please prepare an oral or written statement on the subject of My grandmother, My grandfather." And a second task: "Old people are sometimes sent by their families to Nursing Homes, and terminally-ill people to hospices. Please express your opinion on this subject."(ibid., p. 53)

3) a reading (Polnisch für Fortgeschrittene), consisting of a dialogue between a mother and a daughter. The mother takes her daughter's children on holiday, and the daughter tells her what the children may and may not do. The text is mainly used to illustrate grammar (using the instrumental case and imperative) and expressing bans and

27 J. Duszyńska, Stereotypy wiekowe jako samospetniajaca się przepowiednia [in:] Oblicza..., vol. 2, p. 18 . 
commands. The "Beloved grandma" is someone who will probably disregard her daughter's recommendations, because she had previously made an agreement with her grandchildren to allow them to do the things forbidden by their mother. The grandmother is therefore portrayed as someone who is loved by her grandchildren and who does not give in to her daughter but follows her own judgement.

4) The analysed textbooks failed to provide any other examples, apart from those already mentioned, in which old age would constitute a topic as such. All the examples mentioned concern old age as an additional subject and appear in books at high level of language proficiency (at least B2). Old age, however, is not the main topic of any lesson unit. The approach to it is very stereotypical (both positive and negative stereotypes).

\subsection{Old age in textbooks used for teaching German as a foreign language}

In textbooks for teaching German as a foreign language, old age appears both as a main theme and as a secondary theme (supporting, accompanying). As an accompanying theme, it is often found under the topic of volunteering. FSJ or freiwilliges soziales Jahr (voluntary social year - in Polish - dobrowolny rok socjalny) is a long-term, legally regulated form of volunteering in Germany, in which about 35,000 young people participate each year. Volunteers often work in integration centres, with older and disabled people, in hospitals, hospices, social welfare homes etc. ${ }^{28}$. People between the ages of 16 and 27 can participate in FSJ, which is why this topic is often present in newer textbooks for young people (cf. e.g. Rundum).

In comparison to the results of the analysis of textbooks for teaching Polish as a foreign language (as well as textbooks for teaching other languages, primarily English and Russian), German textbooks contain a lot more materials regarding the subject of old age; these are both reading the majority) and listening texts. Old age is a theme often addressed in exam papers (using photos as a stimulus for speaking). In addition, in its inventory of educational materials the Goethe-Institut has, among others a film dedicated to a grandson's love for his elderly grandmother, entitled Gregors größte Erfindung. This is a short film by Johannes Kiefer adapted as teaching material ${ }^{29}$.

The above study allows us to conclude that there is significant asymmetry between the body of texts being examined with both quantitative and qualitative differences. In German textbooks old age as a theme is much more common and it is a starting point for many different activities and didactic exercises (oral and written). The topic of old age appears in texts designed for reading and listening, for lexical and grammatical exercises, for tasks for independent writing and speaking, and the issues related to old age are also topics for discussion.

The common factor for both groups of textbooks is the occurrence of the topic at a rather higher levels of language proficiency, and in textbooks intended for young people or adults (not for children).

${ }^{28}$ Cf. e.g. http://wolontariat.org.pl/redakcja/news2374/ (access: 30 March 2017).

${ }^{29}$ In 2002, the film was nominated for an Oscar in the category for best short film. Information about the adapted version is available at: http://www.goethe.de/ins/us/bos $/ \mathrm{prj} / \mathrm{kgs} / \mathrm{kur} / \mathrm{gge} / \mathrm{deindex} . \mathrm{htm}$ (access: 30 March 2017). 


\subsection{Old age as the main theme}

In the following textbooks old age, older people, generations and stages of life were titles of chapters or subsections that contained content related to old age and the life of older people, in the form of various types of teaching tasks: Themen neu 2, Auf neuen Wegen, Unterwegs, Aktuelle Texte 3, Studio d 1, Stufen International 1, Aussichten, Schritte, International, Ziel B2, Sichtwechsel 2, Zwischen den Pausen 1, Erkundungen C 1, em Abschlusskurs, Aktuelle Texte, Lernziel Deutsch (Grundstufe 2). The last two of these are the oldest textbooks (Aktuelle Texte 1987, Lernziel Deutsch 1997), which are rarely used today. The remaining ones are textbooks which are currently used as so-called leading, and supplementary material.

In these sources the image of old age which appears in the oldest textbooks - Aktuelle Texte 3, Lernziel Deutsch - is mostly or wholly negative. The only positive image of old age is in Sichtwechsel 2, Zwischen den Pausen, Abschlusskurs, Ziel B2, Aussichten B1 and Schritte International. In the others we are dealing with a mixed or mostly positive image. Below I am going to present a few examples of how old age and older people are written about in the textbooks I studied.

In the textbook Lernziel Deutsch, a reading comprehension text entitled Probleme im Alter describes two older people, one of whom lives a busy life helping other elderly people, but nevertheless he often feels lonely and sad. The other character is an elderly gentleman who does not maintain any social contacts, with the exception of just one friend, who sometimes visits him. One day he falls down in the bathroom and is not able to get up. After two days, his friend finds him and brings help. This chapter also refers to making decisions about living in a retirement home as a good alternative to living alone, and the possibility of being ill or disabled.

A completely different picture of old people emerges from the textbook Schritte International 4. The text Alles, nur nich stehen bleiben, Birgitta shows that a "better life" only began for Birgitta after the age of 56. Until then her life had been a string of sacrifices; at the age of 16 she had had to give up her dreams of acting in the theatre to help her mother; at the age of 26 she gave birth to a third child; throughout her adult life she was devoted to her husband, children and home; at the age of 36 she was often tired; when she was 46 and her children left home she became depressed. It was only 10 years later she became socially involved and her well-being improved. "Now" she is 66 years old and "is feeling great", she enjoys life, and for two years she has even been performing in an amateur theatre group.

Apart from a lot of different information about older people, Ziel B2 textbook contains, among others, a text containing surprising statistical data on Being a Senior in Germany ${ }^{30}$ : older people cause far fewer accidents than young people, they often go to rock music concerts; 37,000 pensioners study at German universities and their favourite subject is history; 14 million Germans are over 65; a German citizen lives on average twice as long as his countryman in the 19th century; the number of centenarians is growing rapidly.

The narrator in the text Mein Tag - Edith Kannengießer (which is an adapted version of an article from "Die Zeit" in Sichtwechsel 2 textbook) is the Edith of the title, a real person, an older lady who has had a heart transplant, is living in a nursing home and is still working professionally (she works in a public toilet). The entire text is a fast-moving monologue by this "toilet grandmother" about her everyday life. Edith works, helps in the nursing home,

${ }^{30}$ Alt sein in Deutschland (Ziel B2). 
feels sorry for all the younger malcontents and enjoys every moment of her life. Edith speaks as a representative of the older generation and testifies that joyous old age is possible.

Another example of resourcefulness and foresights in mature age is Henning Scherf, another real person, an SPD politician and former mayor of Bremen, who published a book entitled Grau ist bunt: Was im Alter möglich ist. The book, its author, and his ideas for the very mature, the silver generation (grau - grey) to take on colour and become bunt, (i.e. colourful) are mentioned in the reading entitled Privatier in the textbook Aussichten B1. Scherf and his wife decided that after retiring they would find a place to live together with their friends, creating a so-called housing community, in which everyone had their own space, but also obligations towards the others. The plan was well thought out and prepared, and the proposed residents of the community got to know each other during common trips and outings. This idea and its implementation were described by German newspapers. The text in the textbook is a version of the article from the daily newspaper Der Tagesspiegel adapted for teaching. Scherf, like Edith Kannengießer, an real person, confirms the fact that old age does not have to be sad and lonely, and that you should plan and prepare for it yourself ${ }^{31}$. His testimony is credible, because Scherf speaks about facts from his life, and it is also supported by his authority as a popular politician and long-time mayor of Bremen.

As can be seen from the examples described above, presenting the theme of old age in textbooks is done through fictional texts, as well as authentic texts and data, such as statistical data or statements given by people. In the language of advertising it is called a testimonial. In several of the analysed textbooks, literary texts are also used to present the topic under consideration. For example, the textbook Studio d Bl contains fragments of the book Die blauen und die grauen Tage by Monika Feth. This is a novel for children about a granddaughter who loves her grandmother who is showing the early symptoms of dementia. Granddaughter Evi decides to keep a diary to prove that "grey days" happen to grandma less often than "blue days", so she can stay at home with the family and she should not think about moving to a nursing home.

Another example of this is the story, Die unwürdige Greisin by Bertolt Brecht in the textbook em Abschlusskurs, which serves as a starting point for an oral and written discussion about the life of older people, petty-bourgeois morality and social expectations towards women, wives, and mothers.

The examples described above are just a small number of the possible examples I could have selected from the large amount of material provided in the analysed textbooks. The characteristic features involve the duality of the phenomenon: firstly by presenting older people as people who need concern and care in their surroundings. In this context tasks related to speaking about retirement homes, often appear especially in older textbooks. The newer textbooks introduce the notion of dementia - "the epidemic of the 21st century". Secondly, older people are presented as people who can teach "life wisdom" and a positive attitude towards life, people who do quite well in society. The newer textbooks typically present a more positive message, which is supported by statements and testimonials made by real people.

${ }^{31} C f$. also the interview with H. Scherf https://www.welt.de/wirtschaft/article114515374/Heutekoennen-viele-mit-60-Jahren-Baeume-ausreissen.html (access: 30 March 2017). 


\section{CONCLUSIONS}

The analysis of textbooks shows that the notion of old age, including the infirmity of old age, in Polish textbooks is given almost no attention. In German textbooks this issue has been covered since the nineties. Germany has encountered the problem of an "ageing society" much earlier. These days, old people make up about 20 percent of society in Germany. From the German textbooks, a diverse picture of old age emerges, but on the whole it carries a positive message. Inconveniences of the "silver" age are heard of less frequently and less intensely. Old/older people are usually active, they pursue their passions, they study, they decide for themselves, they consciously prepare, and carry out plans for their old age, they have alternatives in choosing their place of residence (family, nursing home or housing community with other older people). Language teaching tasks which appear frequently include mentioning the arguments "for" and "against" living in nursing homes, imagining the life of older people and playing their roles are a way of drawing attention to these issues. These sensitise us to the needs of older people and to the signals coming from them. It is perhaps also in some sense a preparation (mental, though perhaps not entirely conscious) for one's own old age and gives us the opportunity to form an opinion, or for students to review their own views (both educational and upbringing-related values) on old age, seniors and their role and status in society. The presence of this theme in German textbooks shows that society in Germany has not only noticed this demographic problem, but is also trying to tackle all aspects of the issue, not only those associated with brain function. They are pragmatic in their attitude which is characterised by an openness in approaching problems and discussing them.

The lack of this topic in the Polish textbooks examined may indicate that a few years ago, when the textbooks were being prepared, Polish society had not yet noticed this problem, or that the problem did not exist on a large enough scale and was therefore not important enough. Time will tell if this topic will appear in textbooks that are currently being written. It seems, however, that such issues as nursing homes, and old age in the family are still taboo in Poland, or are seen as issues that until recently have been treated perhaps too idealistically, referred to in the public discourse as "traditional Polish" - family and Christian - values. It could be assumed that the problem of older people, if it exists at all, would find a solution based on these values. Even if this is to a large extent happening, it certainly does not completely eliminate the problems of the elderly, especially those related to illness, infirmity, loneliness, and insufficient means to live on. The results of these problems are often manifested in the bitterness older people, their lack of a sense of dignity and their low status in society. In the Polish language textbooks for foreigners you cannot hear the voice of seniors. Instead they are largely unnoticed, or at least strongly marginalised.

The described differences may also indicate another approach to the problem of old age, and thus differences in the mentality of societies - Polish society (idealistic approach) and German (pragmatic). Idealising the world presented is a characteristic feature of textbooks (school books), as is their content being "out of date"- they lag behind in relation to current public discourse. However, it is a fact that old age is a notion which is becoming more and more interesting for us all both privately and publicly. This is why old age should be talked about by everyone, including the younger for example, in foreign language classes and through the content of textbooks. 


\section{REFERENCES}

1. Adamzik K., Kontrastive Textologie am Beispiel des Schulbuchs, ,tekst i dyskurs - text und diskurs" 2012, 5, p. 53-91.

2. Bartmiński J., Pojęcie językowego obrazu świata i sposoby jego operacjonalizacji [in:] Jaka antropologia literatury jest dzisiaj możliwa?, P. Czapliński, A. Legeżyńska, M. Telicki (eds.), Poznań 2010, p. 155-178.

3. Bilut-Homplewicz Z., Prinzip Perspektivierung. Germanistische und polonistische Textlinguistik - Entwicklungen, Probleme, Desiderata. Teil I: Germanistische Textlinguistik. Frankfurt am Main 2013.

4. Czachur W., Dyskursywny obraz świata. Kilka refleksji, „tekst i dyskurs - text und diskurs” 2011, 4, p. 79-99.

5. Czachur W., Diskursive Weltbilder im Kontrast. Linguistische Konzeption und Methode der kontrastiven Diskursanalyse deutscher und polnischer Medien, Wrocław 2011.

6. Czachur W., Miller D., Niemiecka lingwistyka dyskursu. Próba bilansu i perspektywy, „Oblicza Komunikacji” 2012, 5, p. 25-43.

7. Dałek E., Belferska refleksja na temat licealistów recepcji starości... Rozważania w kontekście lektur nowej podstawy programowej z języka polskiego w szkole ponadgimnazjalnej [in:] Oblicza starości we wspótczesnym świecie. Perspektywa spoteczno-kulturowa, M. Guzewicz, S. Steuden, P. Brudek (eds.), Lublin 2015, p. 413-428.

8. Dreesen P., Judkowiak J., Bierni na Wschodzie, ponoszacy zbiorowa wine i oczywiście obecni w Europie - krytyka niemieckich i polskich podręczników do historii $w$ oparciu o kontrastywna lingwistyke dyskursu, „tekst i dyskurs - text und diskurs“ 2012, 5, p. 93-126.

9. Duszak A., Tekst, dyskurs, komunikacja międzykulturowa, Warszawa 1998.

10. Duszyńska J., Stereotypy wiekowe jako samospetniająa się przepowiednia [in:] Oblicza starości we wspótczesnym świecie. Perspektywa psychologiczno-medyczna, P. Brudek, S. Steuden, I. Januszewska, A. Gamrowska (eds.), v. 1, Lublin 2015, p. 15-25.

11. Feth M., Die blauen und die grauen Tage, München 1996.

12. Gałuszka M., „Siwiejąca populacja”: ekonomiczna, społeczna i etyczna waloryzacja starości. http://www.annalesonline.uni.lodz.pl/archiwum/2007/2007_02_galuszka_83_93. pdf.

13. Gansel C., Zum textlinguistischen Status des Schulbuchs [in:] Linguistik und Schulbuchforschung. Gegenstände-Methoden - Perspektiven, J. Kiesendahl, C. Ott (eds.), Göttingen 2015, p. 111-135.

14. Guzewicz M., Steuden, S., Brudek P., [eds.], Oblicza starości we wspótczesnym świecie. Perspektywa spoteczno-kulturowa, v. 2, Lublin 2015.

15. Hermanns F., Sprachgeschichte als Mentalitätsgeschichte. Überlegungen zu Sinn und Form und Gegenstand historischer Semantik [in:] Sprachgeschichte des Neuhochdeutschen. Gegenstände-Methoden - Theorien, A. Gardt, K. J. Mattheier et al. (eds.), Tübingen 1995, p. $69-102$.

16. Höhne T., Schulbuchwissen. Umrisse einer Wissens - und Medientheorie des Schulbuchs, Frankfurt/M 2006.

17. Jakubowska H., Raciniewska A, Rogowski Ł., [eds.] Patrząc na starość, Poznań 2009.

18. Kiesendahl J., Ott C., [eds.], Linguistik und Schulbuchforschung. Gegenstände - Methoden-Perspektiven, Göttingen 2015.

19. Kita M., Jęzkowe rytuały grzecznościowe, Katowice 2005. 
20. Labocha J., Dyskurs jako proces przekazywania wiedzy [in:] Dyskurs edukacyjny, eds. T. Rittel, J. Ożdżyński, Kraków 1997, p. 31-37.

21. Lewandowska-Pająk C., Potrzeby osób starszych prezentowane w reklamach telewizyjnych [in:] Oblicza starości we wspótczesnym świecie. Perspektywa społeczno-kulturowa, M. Guzewicz, S. Steuden, P. Brudek (eds.), Lublin 2015, p. 469-479.

22. Nocoń J., Podręcznik szkolny w dyskursie dydaktycznym - tradycja i zmiana, Opole 2009.

23. Potent-Ambroziewicz M., Starość w języku młodzieży współczesnej, Lublin 2013.

24. Tokarski R., Słownictwo jako interpretacja świata, [in:] Wspótczesny język polski, J. Bartmiński (eds.), Lublin 2001, p. 343-370.

25. Wciórka B., Czy zmienia się stosunek Polaków do starości? Raport z badań, luty 2007, www.cbos.pl

26. Wiater W., Das Schulbuch als Gegenstand pädagogischer Forschung [in:] Schulbuchforschung in Europa - Bestandsaufnahme und Zukunftsperspektive, W. Wiater (eds.), Bad Heilbrunn 2003, p. 11-32.

27. Witosz B., Kategoria dyskursu w polonistycznej edukacji akademickiej [in:] Jak analizować dyskurs. Perspektywy dydaktyczne, W. Czachur, A. Kulczyńska, Ł. Kumięga (eds.), Kraków 2016, p. 19-39.

28. Zalewska E., Obraz świata podręcznikach szkolnych do klas początkowych, Gdańsk 2013.

The examples presented in the article come from the following textbooks used for teaching Polish as a foreign language:

1. Butcher A., Janowska I., Przechodzka G., Zarzycka G., Celuję w C2. Zbiór zadań do egzaminu certyfikatowego z języka polskiego jako obcego na poziomie C2, Kraków 2009.

2. Karolak S., Wasilewska D., Polnisch für Fortgeschrittene, Warszawa 1974.

3. Lipińska E., Dąmbska E., Kiedyś wrócisz tu, v. I, B2 level, Kraków 2003.

and for teaching German as a foreign language:

1. Bahlmann C., Breindl E., Dräxler H-D., Ende K., Storch G., Unterwegs, Langenscheidt Berlin-München 2000.

2. Aufderstraße H., Bock H., Müller H., Müller J., Themen neu 2, Max Hueber Verlag Ismaning 2003.

3. Bachmann S., Gerhold S., Müller B-D., Wessling G., Sichtwechsel 2, Ernst Klett Verlag 2000.

4. Buscha A., Raven S., Linthout G., Erkundungen C 1, Schubert-Verlag Leipzig 2009.

5. Dallapiaza R-M., Evans S., Fischer R., Kilimann A., Schümann A., Winkler M., Ziel B2, Hueber Verlag Ismaning 2011.

6. Eggers D., Wiemer C., Müller-Küppers E., Willkop E-M., Auf neuen Wegen, Max Hueber Verlag Ismaning 2003.

7. Faigle I., Rundum. Einblicke in die deutschsprachige Kultur, Stuttgart 2010.

8. Funk H., Kuhn Ch., Demme S., Winzer B. et al., Studio $d$ B1, BC EDU-Cornelsen, BerlinWarszawa 2007.

9. Hegyes K., Marlok Z., Maros J., Kautz M., Somló K., Szalay G., Zwischen den Pausen 1, Verlag für Deutsch Ismaning 1997.

10. Hieber W., Lernziel Deutsch Grundstufe 2, Max Hueber Verlag, Ismaning 1997. 
11. Hilpert S., Kerner M., Niebisch D., Specht F., Weers D., Reimann M., Tomaszewski A. et al., Schritte International 4, Hueber Polska 2012, Ismaning 2008 (1. Auflage).

12. Perlmann-Balme M., Schwalb S., Weers D., em Abschlusskurs, Max Hueber Verlag Ismaning 2008.

13. Ros-El Hosni L., Swerlowa O., Kötzer S., Jentges S., Sokolowski K., Reinke K., Precht J., Aussichten B1, Ernst Klett Sprachen, Stuttgart 2012.

14. Seeger H., Zuleeg H., Aktuelle Texte 3. Lesen, Hören, Diskutieren und Schreiben. Arbeitsbuch für Deutsch als Fremdsprache, Ernst Klett Verlag, Stuttgart 1987.

15. Vorderwülbecke, A., Vorderwülbecke K., Stufen International 1, Ernst Klett International Stuttgart 1999.

\section{I ŻYLI DEUGO I SZCZĘŚLIWIE? OBRAZ STAROŚCI I OSÓB STARSZYCH W PODRECCZNIKACH DO NAUKI JĘZYKA OBCEGO}

Celem artykułu jest prezentacja wyników analizy podręczników do nauki języka obcego, głównie języka niemieckiego, pod kątem obecności w nich tematów dotyczących starości jako zjawiska społecznego i etapu życia człowieka. Okazuje się bowiem, że temat ten występuje jako osobny zakres tematyczny właściwie tylko w podręcznikach do nauki języka niemieckiego jako obcego. Powstaje zatem pytanie, dlaczego obecny jest on tylko w tej grupie podręczników, brakuje go zaś w podręcznikach do nauki języka angielskiego, rosyjskiego lub polskiego jako obcego. Temat starości coraz częściej podejmowany jest w Polsce na forum publicznym i seniorzy powoli stają się nie tylko przedmiotem, ale i podmiotem tej dyskusji. Jednak tendencja ta nie znajduje odzwierciedlenia w zbadanych tutaj podręcznikach do nauki języka polskiego jako obcego. Być może polskie podręczniki nie zdążyły jeszcze zareagować na zmiany demograficzne w społeczeństwie, albo starość i problemy ludzi starszych nie są na tyle istotne, by poświęcać im miejsce w medium, z którego w przeważającej mierze korzystają ludzie młodzi i im jest dedykowane. Podręcznik rozumiany jest tu jako medium społeczne, które współkształtuje obraz rzeczywistości pozajęzykowej, podobnie zresztą jak inne mass media. Na podstawie analizy podręczników i sposobów przedstawiania w nich różnych zjawisk możliwa jest zatem rekonstrukcja nie tylko dyskursów naukowych w dziedzinie macierzystej dla danego podręcznika, ale i dyskursów społecznych, mentalności wspólnot językowych, przemian zachodzących w poszczególnych wspólnotach. Z jednej strony podręczniki konstruują bowiem prezentowaną rzeczywistość, zaś z drugiej stanowią jej rezultaty.

Słowa kluczowe: starość, obraz starości, seniorzy, podręcznik, podręcznik do nauki języka obcego, dyskurs.

DOI: $10.7862 /$ rz.2018.hss.87

Tekst złożono do redakcji: sierpién 2018 r.

Tekst przyjęto do druku: grudzień 2018 r. 
